\title{
RELAXATION ACTIVITY OF TETANUS (LEEA AEQUATA L.) LEAF ETHANOLIC EXTRACT ON GUINEA PIG ISOLATED TRACHEA
}

\author{
NAHITMA GINTING ${ }^{1}$, EDY SUWARSO ${ }^{2}$, DAUD VINCEN RUMAPEA ${ }^{2}$, NERDY NERDY ${ }^{1 *}$ \\ ${ }^{1}$ Department of Pharmaceutical Chemistry, Faculty of Pharmacy, University of Sumatera Utara, Medan, Sumatera Utara, Indonesia. \\ ${ }^{2}$ Department of Pharmacology, Faculty of Pharmacy, University of Sumatera Utara, Medan, Sumatera Utara, Indonesia. Email: \\ nerdy190690@gmail.com
}

Received: 07 March 2018, Revised and Accepted: 25 March 2018

ABSTRACT

Objective: The aim of this study is to determine the relaxation activity of the ethanolic extract of tetanus leaf (EETL) against contracting isolated guinea pig trachea induced by acetylcholine.

Methods: Isolated trachea was equilibrated for 45 min until a stable condition in the Creb's solution with a temperature of $37^{\circ} \mathrm{C}$ aerated with carbogen gas $\left(\mathrm{O}_{2}: \mathrm{CO}_{2}=95 \%: 5 \%\right)$. Test of the relaxation effect conducted after guinea pig trachea contracted with maximum acetylcholine concentration $\left(\mathrm{EC}_{80}: 2.0449 \times 10^{-3} \mathrm{~mol}\right)$ and then a cumulative with concentration of EETL $(0.5 \mathrm{mg} / \mathrm{mL}-4 \mathrm{mg} / \mathrm{mL})$ and concentration of atropine sulfate $\left(6.95 \times 10^{-6} \mathrm{mg} / \mathrm{mL}-2.08 \times 10^{-2} \mathrm{mg} / \mathrm{mL}\right)$.

Results: The results showed that EETL could lower the contraction smooth muscle of guinea pig trachea induced by acetylcholine. EETL at a concentration of $3.5 \mathrm{mg} / \mathrm{mL}$ had the ability to relax the muscle. It was not significantly different compared to that of atropine sulfate $6.95 \times 10^{-3} \mathrm{mg} / \mathrm{mL}$ $(\mathrm{p}>0.005)$.

Conclusion: EETL has a relaxation effect on smooth muscle of guinea pig isolated trachea.

Keywords: Isolated trachea, Guinea pig, Tetanus leaf, Relaxation.

(C) 2018 The Authors. Published by Innovare Academic Sciences Pvt Ltd. This is an open access article under the CC BY license (http://creativecommons. org/licenses/by/4. 0/) DOI: http://dx.doi.org/10.22159/ajpcr.2018.v11s1.26557

\section{INTRODUCTION}

Tetanus is an acute disease, caused by secreted exotoxin of Clostridium tetani. There are 209,000 tetanus infections estimated in 2015, and 200,000 of them result in complications with other diseases such as laryngospasm, fractures, hypertension, abnormal heart rhythm, pneumonia, and will be going to death. Tetanus can arise when a wound comes in contact with soil, road dust, or manure (while gardening). In this anaerobic environment, the spores develop and the toxins that form will spread in the body [1].

One treatment of muscle spasms is by administering relaxation agent. These drugs are used to relax muscles and reduce the sensitivity of neural networks to stimuli. Atropine sulfate is used as an antispasmodic and antidote for insecticide group organophosphate. Utilization of natural materials as traditional medicine has long been developed. This is because people are aware of the side effects caused by the use of synthetic drugs greater than traditional medicine, besides traditional medicine has eased in the acquisition and manufacture. Thus, traditional medicine is a field that is still in a great demand for research [2]. The traditional medicine aslo safe and no toxic compared to conventional medicine $[3,4]$.

Leaves of tetanus (Leea aequata L.) is a medicinal plant that used as antitetanus medicine and to overcome the wound by the people of Tanah Karo, Sumatera Utara, Indonesia. The stems and roots are used as astringent, anthelmintic, indigestion, jaundice, chronic fever, and malaria. The leaves and twigs are used as an antiseptic and treat wounds [2]. Tetanus leaf contains secondary metabolites alkaloids, glycosides, steroids/terpenoids, flavonoids, and tannins. Flavonoids are known to have biological and pharmacological activity tested by in vitro as antiallergic, anti-inflammatory, antioxidant, antibacterial, anticancer, and antidiarrheal. While based on the study, tetanus leaf ethanolic extract ( $L$. aequata L.) has a relaxation effect on the contraction of the isolated guinea pig ileum muscle induced by acetylcholine. The pharmacological activity of tetanus leaf in decreasing contraction of tracheal smooth muscle has never been scientifically tested. The researchers were interested to examine the relaxation activity of tetanus ethanolic extracts on separate guinea pig trachea by in vitro using the organ bath

\section{MATERIALS AND METHODS}

Tools

The tools used in this study include laboratory glassware, analytical balance (Boeco), animal weights (Presica Geniweigher), organ preparation equipment (Belart Products), Vortex (Boeco), stirrer (Dell), organ bath (Belart Products), Isometric transducers (Adinstruments), computer (Adinstruments), microvolume pipette (Socorex), heating and magnetic stirrer (Velp Scientifica), thermostat (Adinstruments), PowerLab (Adinstruments), and Quad Bridge Amplifier (Adinstruments).

\section{Materials}

The samples used in this study were tetanus leaf (L. aequata L.), the chemical used was Creb's solution (consisting of $\mathrm{NaCl}, \mathrm{KCl}$, $\mathrm{MgCl}_{2}, \mathrm{NaH}_{2} \mathrm{PO}_{4}, \mathrm{CaCl}_{2}, \mathrm{NaHCO}_{3}$, and D-Glucose) (Merck), carbogen gas containing $95 \%$ oxygen and $5 \%$ carbon dioxide (Tri Gases), acetylcholine chloride (Sigma), atropine sulfate (Sigma), dimethyl sulfoxide (DMSO) (Merck), and distilled water. This study uses guinea pigs as experimental animals, and the use of animals has been approved by the issuance of a letter of recommendation of Health Research, Ethical Approval from Animal Research Ethics Committees of Faculty of Mathematics and Natural Sciences with the recommended number: 076/KEPH-FMIPA/2017. Tetanus (Leea aequata L.) leaf sample was identified at Herbarium Medanese, University of Sumatera Utara, Medan, Indonesia, 20155.

Determination of acetylcholine chloride effective concentration Tests of muscarinic agonists are performed to measure the maximum limit that can be demonstrated to the smooth muscle contraction 
of tracheal guinea pigs, to obtain a maximum concentration (EC80) acetylcholine chloride. Measurements were performed in stages with cumulative acetylcholine concentrations in the range $10^{-8} \mathrm{~mol}$ to $3 \times 10^{-3}$ mol in organ bath. The isolated guinea pig trachea was measured the contraction for $45 \mathrm{~min}$ (with a changing of Creb's solution every $15 \mathrm{~min}$ ). After the results obtained, then calculated the tracheal contractions induced by acetylcholine chloride. The purpose of the calculation is to obtain an effective concentration of $80 \%$ of acetylcholine that can make the trachea contract. Hence, from the calculation results obtained, the amount of acetylcholine chloride needed to make isolated guinea pig trachea will experience increased contraction.

Relaxation effect test of ethanolic extract of tetanus leaf (EETL) and atropine sulfate

The increases of tracheal contraction, induced by acetylcholine chloride, were done by addition of EETL into organ bath. EETL was obtained by maceration method was given cumulatively to obtain the stratified concentration of $0.5 \mathrm{mg} / \mathrm{mL}-4.0 \mathrm{mg} / \mathrm{mL}$. Atropine sulfate was given cumulatively to obtain the stratified concentration $6.95 \times 10^{-6} \mathrm{mg} / \mathrm{mL}-2.08 \times 10^{-2} \mathrm{mg} / \mathrm{mL}$. The guinea pig trachea should be equilibrated for $45 \mathrm{~min}$ (with a change of Creb's solution every $15 \mathrm{~min}$ ) for contraction and relaxation in the trachea to stabilize. After the guinea pig trachea reaches a stable condition, then the trachea is induced by acetylcholine chloride. After the calculation of effective concentration $80 \%$, it is found that by giving $410 \mu \mathrm{l}$ of $2 \times 10^{-1}$ mol acetylcholine chloride solution will be obtained the maximum subconcentration of $2.0449 \times 10^{-3} \mathrm{~mol}$ acetylcholine chloride in organ bath. So with the giving of acetylcholine chloride $2 \times 10^{-1}$ mol hence already make contraction to isolated guinea pig trachea.

\section{MATERIALS AND METHODS}

Determination of acetylcholine chloride effective concentration Testing of isolated tracheal on smooth muscle contractions by the addition of acetylcholine-treated concentration $\left(10^{-8} \mathrm{~mol}-3 \times 10^{-3} \mathrm{~mol}\right)$ was performed to obtain effective concentration $\left(\mathrm{EC}_{80}\right)$ of acetylcholine which will then be used for testing the relaxing effect of the tetanus leaf ethanolic extract. The results of this test were observed through a change in the contraction response of the isolated tracheal smooth muscle by increasing the concentration of acetylcholine $\left(10^{-8} \mathrm{~mol}-\right.$ $3 \times 10^{-3} \mathrm{~mol}$ ). The results and graph of the contraction of tracheal smooth muscle of guinea pig with the series concentration addition of the acetylcholine can be seen in Table 1 and Fig. 1.

The addition of acetylcholine series concentration causes contraction of the isolated tracheal smooth muscle. The contraction of the tracheal smooth muscle increases with increasing concentrations of acetylcholine. The maximum contraction response of the tracheal smooth muscle is obtained at the concentration of $3 \times 10^{-3} \mathrm{~mol}$ acetylcholine since the higher concentration of acetylcholine no longer shows an increase in

Table 1: Results of the contraction of tracheal smooth muscle of guinea pig with the series concentration addition of the acetylcholine

\begin{tabular}{lll}
\hline $\begin{array}{l}\text { Log. Concentration of } \\
\text { Acetylcholine }\end{array}$ & Mean & $\begin{array}{l}\text { Error } \\
\text { standard }\end{array}$ \\
\hline-8 & & 0.5350 \\
-7.52 & 3.7052 & 1.0009 \\
-7 & 5.6449 & 1.2257 \\
-6.52 & 6.8975 & 1.7131 \\
-6 & 7.8075 & 1.8502 \\
-5.52 & 8.2628 & 2.1886 \\
-5 & 8.4904 & 2.1247 \\
-4.52 & 8.3869 & 2.7423 \\
-4 & 8.9123 & 3.0237 \\
-3.52 & 10.4160 & 6.8324 \\
-3 & 18.2731 & 8.0408 \\
-2.52 & 43.8860 & 0.0000 \\
\hline
\end{tabular}

contraction. The number of receptors limits the effect so that even when the concentration is increased, the response does not increase.

Based on the above description, it can be concluded that tracheal smooth muscle contraction occurs due to stimulation of muscarinic receptors by agonists, in this the research was used acetylcholine as the contraction inducer [5]. The EC80 of acetylcholine obtained was $2.0449 \times 10^{-3} \mathrm{~mol}$. EC80 acetylcholine was used to test the relaxing effect of EETL. The procedure performed was EC80 acetylcholine induced in smooth muscle of isolated guinea pig trachea, then EETL was added and observed a decrease in contraction occurred. The effects of acetylcholine contraction of guinea pig trachea are regulated primarily through M3 muscarinic receptor stimuli in the respiratory tract [6].

Activation of the M3 muscarinic receptor will then activate the phospholipase C (PLC) by combining with Gq protein, which produces two messenger inositol 1,4,5-trisphosphate (IP3) and diacylglycerol (DAG) as a result of hydrolysis of phosphatidylinositol 4,5-bisphosphate (PIP2). IP3 occupies IP3 receptor, thus inducing the release of $\mathrm{Ca}^{2+}$ from sarcoplasmic reticulum (SR) [6]. While DAG will cause influx of $\mathrm{Ca}^{2+}$ from extracellular. The release of $\mathrm{Ca}^{2+}$ from SR and $\mathrm{Ca}^{2+}$ influx will increase the amount of $\mathrm{Ca}^{2+}$ in the cytosol [7]. Increased $\mathrm{Ca}^{2+}$ in the cytosol will form a $\mathrm{Ca}^{2+}$ calmodulin complex that activates myosin light-chain kinase (MLCK) which will phosphorylate MLC, resulting in myosin-action interactions with actin resulting in contraction of smooth airway muscle [6].

\section{Relaxation effect test of EETL and atropine sulfate}

Examination of EETL relaxation effect on isolated tracheal plaque muscle was done by contracting the tracheal plaque muscle with acetylcholine $1.39 \times 10^{-3} \mathrm{~mol}$, then followed by giving the cumulative concentration of EETL $0.5 \mathrm{mg} / \mathrm{mL}-4.0 \mathrm{mg} / \mathrm{mL}$ [8]. Results of the EETL relaxation effect test on guinea pig tracheal smooth muscle can be seen in Table 2, and graph of the EETL relaxation effect test on guinea pig tracheal smooth muscle can be seen in Fig. 2.

\section{Information}

Relaxation is calculated from the maximum contraction point achieved by the administration of acetylcholine $2.0449 \times 10^{-3} \mathrm{~mol}$

Table 2: Results of the EETL relaxation effect test on guinea pig tracheal smooth muscle

\begin{tabular}{lll}
\hline Dose of EETL $(\mathbf{m g} / \mathbf{m L})$ & Relaxation $(\%)$ & Standard Error \\
\hline 0.5 & 35.64170 & 3.2195 \\
1.0 & 56.34416 & 7.3889 \\
1.5 & 71.25400 & 6.0534 \\
2.0 & 74.98624 & 4.1181 \\
2.5 & 89.78866 & 1.9786 \\
3.0 & 97.92138 & 3.7682 \\
3.5 & 106.04392 & 2.5982 \\
4.0 & 106.04392 & 2.5982 \\
\hline
\end{tabular}

EETL: Ethanolic extract of tetanus leaf

Table 3: Results of the atropine sulfate relaxation effect test on guinea pig tracheal smooth muscle

\begin{tabular}{lll}
\hline $\begin{array}{l}\text { Dose of atropine sulfate } \\
(\mathbf{m g} / \mathbf{m L})\end{array}$ & Relaxation $\mathbf{\% )}$ & Standard error \\
\hline $6.95 \times 10^{-6}$ & 48.7621 & 3.6734 \\
$2.08 \times 10^{-5}$ & 63.4220 & 5.9760 \\
$6.95 \times 10^{-5}$ & 68.8707 & 5.6987 \\
$2.08 \times 10^{-4}$ & 78.4721 & 4.9919 \\
$6.95 \times 10^{-4}$ & 86.3040 & 4.5565 \\
$2.08 \times 10^{-3}$ & 96.7794 & 2.6425 \\
$6.95 \times 10^{-3}$ & 106.1748 & 0.6508 \\
$2.08 \times 10^{-2}$ & 107.3513 & 1.2789 \\
\hline
\end{tabular}


Tests of atropine sulfate relaxation effects on isolated tracheal plot muscle were performed by contracting the tracheal smooth muscle with $2.0449 \times 10^{-3} \mathrm{Mol}$ acetylcholine, followed by series of atropine sulfate concentrations of $6.95 \times 10^{-6} \mathrm{mg} / \mathrm{mL}-2.08 \times 10^{-2} \mathrm{mg} / \mathrm{mL}$. Results of the atropine sulfate relaxation effect test on guinea pig tracheal smooth muscle can be seen in Table 3, and graph of the atropine sulfate relaxation effect test on guinea pig tracheal smooth muscle can be seen in Fig. 3.

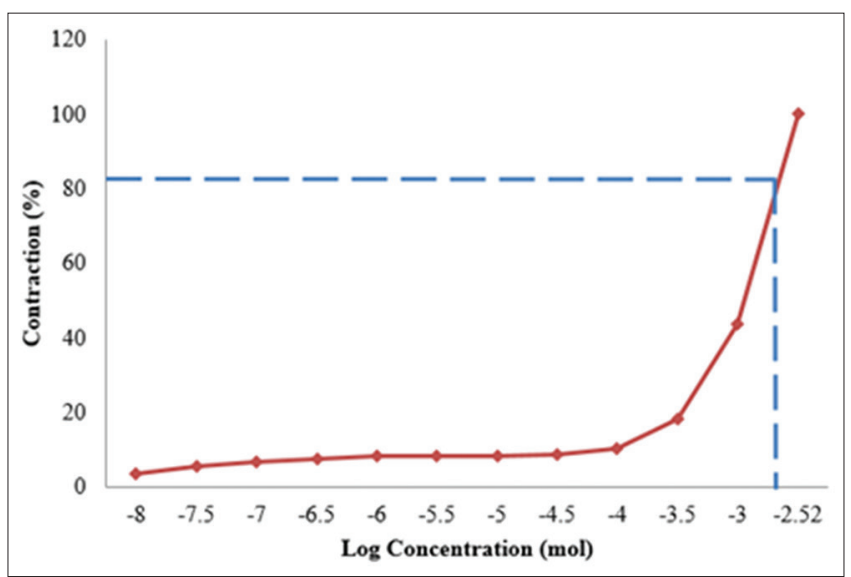

Fig. 1: Graph of the contraction of tracheal smooth muscle of guinea pig with the series concentration addition of the acetylcholine

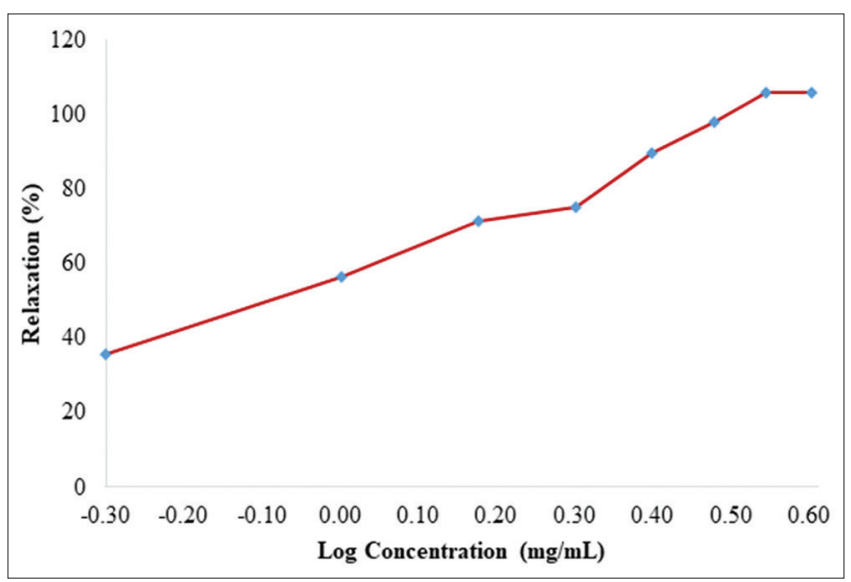

Fig. 2: Graph of the ethanolic extract of tetanus leaf relaxation effect test on guinea pig tracheal smooth muscle

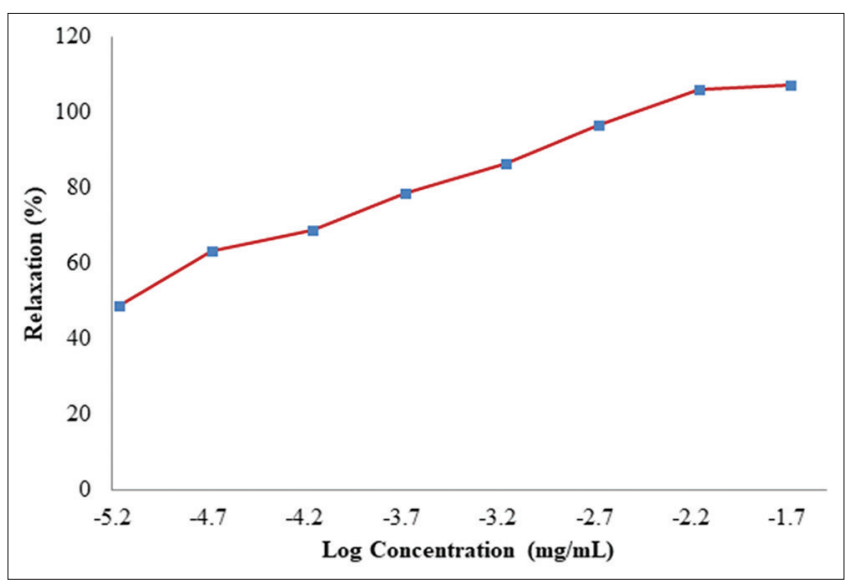

Fig. 3: Graph of the atropine sulfate relaxation effect test on guinea pig tracheal smooth muscle
Information: Relaxation is calculated from the maximum contraction point achieved by the administration of acetylcholine $2.0449 \times 10^{-3} \mathrm{~mol}$

Giving series of EETL concentrations resulted in a relaxation effect on the contraction induced by acetylcholine $2.0449 \times 10^{-3} \mathrm{~mol}$. The addition of EETL concentrations of $0.5 \mathrm{mg} / \mathrm{mL}$ has demonstrated a relaxing effect on tracheal smooth muscle. EETL concentrations of $3.5 \mathrm{mg} / \mathrm{mL}$ showed a relaxation effect that exceeded $100 \%$ of $106.0439 \pm 2.5981 \%$ (Fig. 2). The results of this study show that EETL has a relaxing effect on the smooth muscle of tracheal guinea pigs contracted by acetylcholine. The extract was reconstituted with DMSO and had no effect on tracheal smooth muscle [9]. Based on regression correlation test also obtained significant correlation between EETL concentration with the muscle relaxation effect of guinea pig tracheal muscle $(r=0,981 ; p<0.05)$. This indicates that the relaxation effect that occurs is the result of giving tetanus ethanolic extract.

Tetanus leaves contain secondary metabolites of flavonoids, tannins, glycosides, saponins and steroids/triterpenoids. Flavonoids are known to have a relaxing effect on smooth muscle [10]. Research conducted showed that tetanus contains flavonoid glucuronide compounds, namely, apigenin 7-0- $\beta$-glucuronide, luteolin 7-0- $\beta$-glucuronide, and apigenin 7-0- $\beta$ - (2 “-0- $\alpha$-rhamnosyl) glucuronide. Apigenin has an effect as an anti-asthma [11]. However, the mechanism of the relaxation effect on tracheal smooth muscle generated by EETL has not been elucidated in more detail, since this procedure is only an observation of the profile of decreased contraction of tracheal smooth muscle by EETL.

\section{Comparison of relaxation effect}

Tests of atropine sulfate relaxation effects on isolated tracheal plot muscle were performed by contracting the tracheal smooth muscle with $2.0449 \times 10^{-3} \mathrm{~mol}$ acetylcholine, followed by series of atropine sulfate concentrations of $6.95 \times 10^{-6}-2.08 \times 10^{-2} \mathrm{mg} / \mathrm{mL}$. The relaxation effect of atropine sulfate was observed by observing the $\%$ effect of the relaxation effect of the extract on tracheal organ. Comparison of the relaxation effect between atropine sulfate at concentrations of $6.95 \times 10^{-3} \mathrm{mg} / \mathrm{mL}$ $(101.4771 \pm 1.4679)$ and EETL in the administration of $3.5 \mathrm{mg} / \mathrm{mL}$ extract $(101.9827 \pm 3.0545)$ to tracheal contractions induced by acetylcholine showed that the difference in percentage relaxation between the two did not differ significantly ( $p>0.05)$.

The results of the tests shown in the graph also show that data on the comparison between extract concentration and tracheal smooth muscle relaxation percentage did not give linear results. This may be because the test animals used in this study are not derived from pure strains of guinea pig that have a uniform genotype but animals that have undergone many crosses. The existence of the relaxation effect ability of the EETL is probably due to the presence of secondary metabolites that play a role. Secondary metabolites of L. aequata L. are alkaloids, glycosides, steroids/terpenoids, flavonoids, and tannins. The Leea indica L. (same family with $L$. aequata $\mathrm{L}$.) has a strong sedative effect on mice and has the same secondary metabolite with L. aequata $\mathrm{L}$. $[12,13]$. It is therefore necessary to further investigation of the effect of selective secondary metabolites on tracheal smooth muscle relaxation and its mechanism of action on the trachea.

Tests performed on tracheal smooth muscle can be used as a scientific reference to the treatment of pharmacological diseases of airway constriction or asthma. Trachea and bronchus contain cartilage plates that surround the airway. Cartilage in this channel supports the structure of the trachea and bronchi to prevent collapse. The bronchus continues to branch out to the periphery of the lungs. In the bronchioles no longer found cartilage, but it could found smooth muscle. Therefore, bronchioles, lacking the cartilage to support it and smooth muscles capable of contracting, are susceptible to attacks such as asthma [14].

\section{CONCLUSIONS}

The EETL ( $L$. aequata L.) has a relaxation effect on the smooth muscle contraction of isolated guinea pig trachea induced by acetylcholine 
chloride. The EETL (L. aequata L.) with concentration of $3.5 \mathrm{mg} / \mathrm{mL}$ has not significant different with atropine sulfate with concentration $6.95 \times 10^{-3} \mathrm{mg} / \mathrm{mL}$ in relaxation the contraction of smooth muscle of isolated guinea pig trachea induced by acetylcholine chloride $2.0449 \times 10^{-3} \mathrm{~mol}(\mathrm{p}>0.05)$.

\section{AUTHORS CONTRIBUTION}

This work was carried out in collaboration between all authors. Nahitma Ginting designed the research, Edy Suwarso supervise the research, Daud Vincen Rumapea, and Nerdy did the research work, collected the data, and analyzed the data.

\section{CONFLICT OF INTERESTS}

The authors declare that they have no conflicts of interests.

\section{REFERENCES}

1. Atkinson W. Tetanus Epidemiology and Prevention of VaccinePreventable Diseases. $12^{\text {th }}$ ed. New York: Public Health Foundation; 2012. p. 291-300.

2. Khare CP. Indian Medicinal Plants. New Delhi: Springer Science \& Business Media, LCC; 2007. p. 366.

3. Guinnin FFD, Klotoe JR, Ategbo JM. Acute toxicity evaluation of ethanolic extract of Aristolochia albida Duch. Leaves on wistar rats liver and kidney functions. Int J Pharm Pharm Res 2017;9:35-40.

4. Bouhalit S, Kechrid, Z, and Elfeki A. Effect of silymarin extracted from Silybum marianum on nickel hematotoxicity and nephrotoxicity in male albino wistar rats. Int J Pharm Pharm Res 2017;9:84-9.

5. Oenema TA. Muscarinic Receptors in Airway Smooth Muscle: Roles in inflammation and remodeling. Dissertation. Netherlands: University of Groningen-Netherlands; 2013. p. 15.

6. Gosens R, Zaagsma J, Meurs H, Halayko AJ. Muscarinic receptor signaling in the pathophysiology of asthma and COPD. Respir Res 2006;7:1-15.

7. Hall IP. Second messengers, ion channels and pharmacology of airway smooth muscle. Eur Respir J 2000;4:1120-7.

8. Soares PM, Pires A, Ana MA, Souza EP, Criddle D. Relaxant effects of the essential oil of Mentha pulegium L. in rat isolated trachea and urinary bladder. J Pharm Pharmacol 2012;64:1777-84

9. Saraq B, Altun A, Yildirim S, Yildirim MK, Temiz TK, Bagvican I, et al. Investigation of the relaxant effect mechanism of ketamine on normal and ovalbumin-induced trachea in guinea pigs. Turkiye Klinikleri $\mathrm{J}$ Med Sci 2011;31:1145-52

10. Carron R, Sanz E, Puebla P, Martin ML, Roman LS, Guerrero MF. Mechanisms of relaxation induced by flavonoid ayanin in isolated aorta rings from wistar rats. Colomb Méd 2010;41:1-7.

11. Li J, Zhang B. Apigenin protects ovalbumin induced asthma through the regulation of Th17 cells. Fitoterapia 2013;91:298-304

12. Raihan MO, Habib MR, Brishti A, Rahman MM, Saleheen MM, Manna M. Sedative and anxiolytic effects of the methanolic extract of Leea indica (Burm. f.) merr. leaf. Drug Discov Ther 2011;5:185-9.

13. Rahman MA, Imran TB, Islam S. Antioxidative, antimicrobial and cytotoxic effects of the phenolics of Leea indica leaf extract. Saudi J Biol Sci 2012;20:213-25.

14. Sellers DJ, Williams RC. In: Fryer AD, Christopoulos A, Nathanson NM. Muscarinic agonists and antagonists: Effects on the urinary bladder. Handbook of Experimental Pharmacology: Muscarinic Receptors. Vol. 208. Germany: Springer-Verlag, Berlin Heidelberg; 2012. p. 375- 400 